\title{
Fish assemblage structure in a port region of the Amazonic coast
}

\author{
Marcelo H. L. Silva',2 (D) https://orcid.org/0000-0003-2579-5690 \\ Audálio R. Torres Júnior ${ }^{2}$ (D) https://orcid.org/0000-0003-1864-2645 \\ Antonio C. L. Castro 3 (1) https://orcid.org/0000-0002-8681-4587 \\ James W. J. Azevedo' (D) https://orcid.org/0000-0002-7034-4592 \\ Cássia F. C. Ferreira ${ }^{2}$ (1) https://orcid.org/0000-0001-8626-5007 \\ Rayssa L. Cardoso 2 (1) https://orcid.org/0000-0002-6186-6866 \\ Jorge L. S. Nunes 1,2 (D) https://orcid.org/0000-0001-6223-1785 \\ Raimunda N. F. Carvalho-Neta ${ }^{1,2}$ (1) https://0000-0002-3519-5237
}

\section{Universidade Federal do Maranhão, Programa de Pós-Graduação - Rede de Biodiversidade e Biotecnologia da Amazônia Legal (BIONORTE) Doutorado em Biodiversidade e Biotecnologia, Av. dos Portugueses, 1966, Bacanga, 65080-805 São Luís, Maranhão, Brazil. (marceloh10@gmail.com) \\ 2. Universidade Estadual do Maranhão, Programa de Pós-Graduação em Recursos Aquáticos e Pesca (PPGRAP), Campus Paulo VI, São Luís, Maranhão, Brazil. \\ 3. Universidade Federal do Maranhão, Programa de Pós-Graduação em Saúde e Ambiente, Av. dos Portugueses, 1966, Bacanga, 65080-805 São Luís, Maranhão, Brazil.}

ABSTRACT. The fish assemblage structure in a port area in São Marcos Bay (Amazonic coast) was evaluated based on the spatial and temporal distributions to identify potential changes in response to anthropic pressure increases associated with industrial and port activities in region. The samples were taken between March 2011 and November 2015. The ichthyofauna was represented by a total of 56 species, distributed in 15 orders and 29 families. Captures were dominated by Genyatremus luteus (Bloch, 1790), but Sciades proops (Valenciennes, 1840) was the most representative in terms of biomass. Seasonal distributions of fish assemblage did not reveal significant differences. However, there was a difference between catch sites, abundance, biomass and Shannon diversity index was higher in the Site 1 and evenness in Site 4. The analysis NMDS and the test ANOSIM between months and between sampling sites, based on species composition, revealed a seasonal differentiation associated with the rainy and drought months, as well as spatial differentiation, in function of a depth gradient and hydrodynamics, resulting from greater distance from mangrove areas. The low diversity recorded may be a reflection of port activities that historically occur in the area investigated. However, there was still a maintenance of regional diversity throughout the period under analysis. Thus, temporal and spatial scales become important for the detection and understanding of fish biodiversity in an Amazonian estuary, reflecting, the importance of mangroves for the maintenance of the ichthyofaunistic diversity in the area. In this context, the present study may subsidize possible conservation projects in the area since information of this nature is almost non-existent for estuarine fish from the Maranhão Amazon.

\section{KEYWORDS. Ichthyofauna, estuary, seasonal variability, spatial patterns, Maranhão Amazon.}

RESUMO. Estrutura da assembleia de peixes em uma região portuária da costa amazônica. A estrutura da assembleia de peixes em uma área portuária na Baía de São Marcos (Costa Amazônica) foi analisada com base nas distribuições espaciais e temporais para identificar potenciais mudanças na resposta aos aumentos de pressão antrópica associados às atividades industriais e portuárias na região. As amostras foram realizadas entre março de 2011 a novembro de 2015. A composição da ictiofauna foi representada por um total de 56 espécies, distribuídas em 15 ordens e 29 famílias. As capturas foram dominadas por Genyatremus luteus (Bloch, 1790), mas Sciades proops (Valenciennes, 1840) foi o mais representativo em termos de biomassa. A avaliação sazonal da assembleia de peixe não revelou diferença significativa. Entretanto, houve diferença entre os locais de captura onde abundância, biomassa e diversidade de Shannon foram mais relevantes no Ponto 1 e a equitabilidade no Ponto 4. A análise NMDS e o teste ANOSIM entre os meses e entre os locais de amostragem, com base na composição de espécies, revelaram uma diferenciação sazonal associado aos meses chuvosos e de estiagem, bem como uma diferenciação espacial, em função de um gradiente de profundidade e hidrodinâmica, resultante da maior distância das áreas de mangue. A baixa diversidade registrada podem ser reflexos das atividades portuárias que historicamente ocorrem na área investigada. Porém, ainda sim, percebeu-se uma manutenção da diversidade regional, ao longo do período em análise. Assim, as escalas temporais e espaciais tornam-se importantes para detecção e compreensão da biodiversidade de peixes em um estuário amazônico, refletindo, a importância dos manguezais para a manutenção da diversidade ictiofaunística na área. Mediante este contexto, o presente estudo pode subsidiar possíveis projetos de conservação na área, uma vez que informações desta natureza são quase inexistentes para peixes estuarinos da Amazônia maranhense.

PALAVRAS-CHAVE. Ictiofauna, estuário, variabilidade sazonal, padrões espaciais, Amazônia maranhense. 
Estuaries are important examples of high species richness, abundant biomass, and diversity of biological (spawning, reproduction, recruitment, nursery) and ecological (freshwater, estuarine and marine species migrations/movements, regulation of nutrients, coastal waters fertilization, land-sea connectivity) processes (BARLETTA et al., 2008). Therefore, as a result of its productivity and readily available resources, estuaries have always been directly responsible for the maintenance of the daily lives, and long term survival, of traditional populations worldwide (BARLETTA \& COSTA, 2009).

Along the northern Brazilian coast (Maranhão Gulf) are the most extensive estuarine areas due to the influence of macro tides (6 to $7 \mathrm{~m}$ ), when creeks of mangrove forests are flooded during high tide. Scientific knowledge about the fish fauna of the northern coast of Brazil is still scarce, with diffuse information and several geographic gaps. Studies carried out between Amapá and Maranhão recorded about 303 species belonging to 23 orders and 86 families, which are distributed between two main subareas: the MaranhensesParaenses estuaries and the region between the Amazonian estuary and the Amapá coast (CAMARGo \& ISAAC, 2003). Tropical estuaries are exposed to marine and terrestrial processes, which influences their structural characteristics, affecting the distribution patterns of fish communities (NERO \& SEALEY, 2006).

Estuarine environments, particularly the São Marcos Bay (Brazil), where there is a port area of national and international importance (CARVALHO-NeTA et al., 2014), are characterized by high primary productivity and provide feeding and breeding places for many species of fish and other aquatic organisms, many of which are of commercial value (Viana \& LuCENa FrÉDou, 2014). In this region it is inserted the second largest port complex in the country, which is the main driver of economic and social development in the state of Maranhão (Assis et al., 2013). In this area, the catching of estuarine and marine fish is still of great relevance for the adjacent fishing communities.

Fish communities have great biological importance, as they can influence the composition, abundance and distribution of other biotic communities in estuaries (BORGES et al., 2010). Many species of ichthyofauna depend on estuaries at some stage of their lives for recruitment, breeding and feeding activities (LONERAGAN, 1999; KIMMERER, 2002). Changes in the composition of communities act as an important parameter to indicate the quality of the ecosystem. Thus, several studies have highlighted the ichthyofaunistic community as an indicator of environmental quality (FALCÃO et al., 2008; SILVA-JÚNIOR et al., 2013; MoURÃo et al., 2015; Fisch et al., 2016).

There are different approaches used in describing fish assemblages as well as the factors that influence their variation. Some studies focus on environmental influences on the structure of communities (THIEL et al., 1995; LARA
\& GonzÁlez, 1998; Marshall \& Elliott, 1998; AraúJo et al., 2002), others describe seasonality (MAEs et al., 1998) and some only consider spatial patterns (ARAÚJo et al., 1997, 1998), without determining an effective cause. It is important to take into account anthropic actions in the estuarine habitats and, consequently, in the fish assemblages associated with them, which may directly affect the biological, physiological and behavioral patterns of the species (WHITFIELD \& ELLIOTT, 2002).

Currently, little is known about the temporal dynamics of fish communities in an estuarine environments belonging to the Eastern Amazon. Thus, it is extremely important to identify possible changes in the fish assemblages. Therefore, the aim of this study was to determine the differences in the fish composition, abundance, biomass and diversity, based on a spatial and temporal assessment, and possible influences of anthropic pressure increases associated with industrial and port activities in São Marcos Bay (Amazonic coast).

\section{MATERIALS AND METHODS}

The coast of Maranhão is located between the mouth of the Gurupi River, State of Pará, and the mouth of the Parnaíba River, State of Piauí, approximately $640 \mathrm{~km}$ long. For descriptive purposes it is divided into three distinct areas, West Coast, Maranhense Gulf and East Coast. The Maranhense Gulf is situated in the center region of the coast, where there are two large bays, São Marcos and São José, which are separated by and island called the Island of Maranhão.

Regarding the climate, the coastal region of Maranhão is characterized by the transition between the humid climate of the Amazon and the semi-arid region of the Northeast. In the study area the tropical humid climate is predominant and the average temperature is $24^{\circ} \mathrm{C}$, with rainfall averages

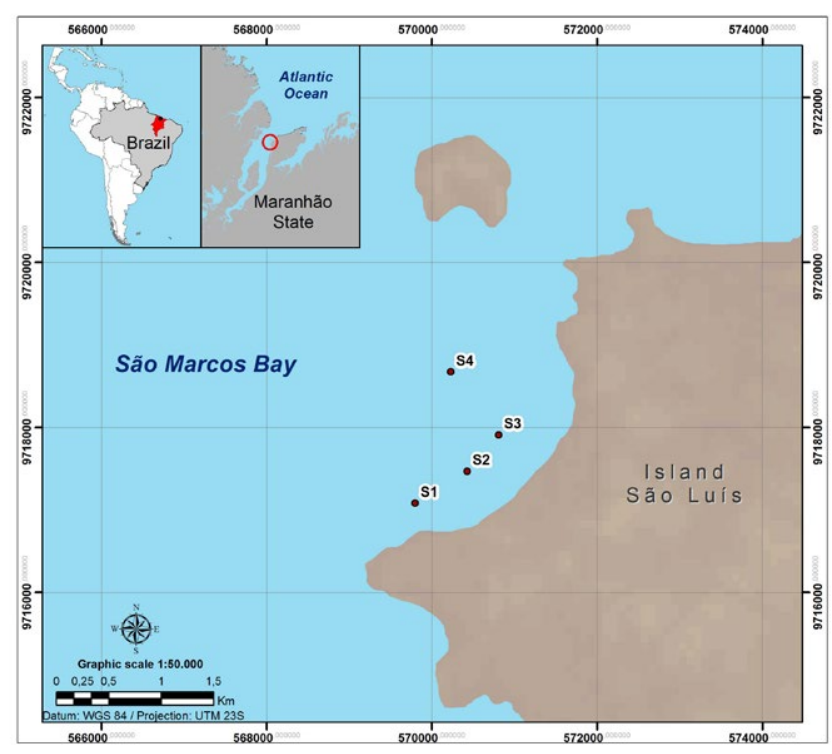

Fig. 1. Sites location at São Marcos Bay, state of Maranhão, Brazil. 
ranging from $1600 \mathrm{~mm}$ to $2000 \mathrm{~mm}$, with the relative humidity of $80 \%$ (STRIDE, 1992). The climate in this region is also characterized by two seasons: dry season and rainy season.

In this study, the sampling was carried out in four distinct sites in São Marcos Bay. The sites are characterized by strong anthropic interference (industrial activities) and by activities developed in the Itaqui port region. Site 1 (44²2'19.745"W, 2³3'34.062”S), which is a more sheltered and the densest area of mangrove plant species; Site 2 (44²1'59.359'”, 2'33'21.469'S) and Site 3 (4421'47.033'”, $\left.2^{\circ} 33^{\prime} 7,150^{\prime \prime} \mathrm{S}\right)$, areas closer to the mainland and under the influence of the port complex; Site $4\left(44^{\circ} 22^{\prime} 5.857^{\prime \prime} \mathrm{W}, 2^{\circ} 32^{\prime} 42.265^{\prime \prime} \mathrm{S}\right)$, which is the farthest site from the port, it is also the deepest site (Fig. 1).

Fish samples were performed from May/2011 to November/2015, with a total of 18 sampling. The species were collected in four sites (S1, S2, S3 and S4) using gillnets, with meshes ranging from $18 \mathrm{~mm}$ to $60 \mathrm{~mm}$ between opposing nodes. The gillnets were installed at the end of the high tide and continued throughout the entire ebb tide cycle (standardized in approximately $6 \mathrm{~h}$ at each sites).

The samples were placed in plastic bags, stored in the ice and taken to the Laboratory of Ichthyology of the Universidade Federal do Maranhão. The biological material was identified up to the species level, using the studies developed by Fischer (1978), CERvigón et al. (1992) and FIGUEIREDo et al. (1980, 2000). In addition, some identifications were updated using the Fishbase database (Froese \& PAuly, 2009). For each specimen, the total length $(\mathrm{cm})$, standard length $(\mathrm{cm})$ and total weight $(\mathrm{g})$ were obtained. Part of the identified material was fixed in $10 \%$ diluted formaldehyde and later preserved in $70 \%$ alcohol. Then, it was stored in the Collection Room of the Laboratory of Hydrobiology of the Universidade Federal do Maranhão.

Fish community parameters (number of fish, biomass, diversity, through Shannon-Wiener index and evenness J' index) were compared between seasons and catching sites. The graphical representation of the data, through the box plot, was made with the aid of the software STATISTICA version 7.0 (Statsoft Corp, USA).

Assumptions of normality and homogeneity of variance were analyzed by Shapiro-Wilk test (SHAPIRO \& WILK, 1965) and Levene test, respectively. When necessary, data were transformed with $\log (\mathrm{x})$ or $\log (\mathrm{x}+1)$. Parametric analysis of variance (ANOVA) or non-parametric KruskalWallis (KW) was used depending on the fulfillment of the assumptions. A post-hoc Tukey's Test or Mann-Whitney was used to test for multiple comparisons between months and sites. The statistical analyzes were performed using the PAST program 3.14 (HAMMER, 2001), with significance level of $\alpha=0.05$ (SoKAL \& RoHLF, 1969).

Temporal variation in the structure of the fish assemblages were evaluated by non-metric multidimensional scaling (NMDS) with 1000 iterations, derived from a BrayCurtis similarity matrix constructed from the fish abundance data, with data transformed to $\log (x+1)$. The R-statistic values determined by ANOSIM for significant comparisons were used to ascertain the degree to which a priori seasonal groups (dry and rainy seasons) and site groups (S1, S2, S3 and S4) were dissimilar (ClARKE, 1993). Similarity Percentages (SIMPER) (CLARKE \& WARWICK, 1994) were employed to determine which species contributed the most to any similarities within exposure groups. These analyses were performed with the statistics program PRIMER v. 6 (CLARKE \& GORLEY, 2006).

\section{RESULTS}

A total of 4,257 individuals from 56 species were collected at four sites along São Marcos Bay between the years of 2011 and 2015. The species were distributed in 14 orders and 29 families, of which $45 \%$ belongs to the order Perciformes, $13 \%$ to the order Siluriformes and $10 \%$ to the Clupeiformes. The orders Mugiliformes, Pleuronectiformes and Tetraodontiformes represented 5\% each, Beloniformes 3\%, Rajiformes $3 \%$ and the remaining represented $12 \%$. The families with the highest number of species were Sciaenidae (12), Ariidae (7), Carangidae (4), Engraulidae (4) and Mugilidae (3).

The species Genyatremus luteus, Sciades proops, Macrodon ancylodon, Bairdiella ronchus, Bagre bagre, Mugil gaimardianus, Sciades herzbergii and Sardinella janeiro were dominant in numbers of individuals representing $63 \%$ of the total catch (Tab. I). Genyatremus luteus was the most abundant taxon, accounting for $10 \%$ of the total catch or 417 individuals.

The total catch weight was $544 \mathrm{~kg}$, in which Sciades proops was the most representative with $20 \%$ (109.9 kg) of the total catch, followed by Macrodon ancylodon, Bagre bagre, Centropomus undecimalis, Genyatremus luteus, Sciades herzbergii, Cynoscion acoupa and Trichiurus lepturus, with a total of $75 \%$ of the sample.

There were higher catches in May/2011, July/2013, August/2015 and November/2015 (Fig. 2), and the species that contributed most to this result were Genyatremus luteus, Lile piquitinga, Bairdiella ronchus, Sciades proops, Sardinella janeiro, Macrodon ancylodon and Mugil gaimardianus. The months with the lowest catch rates were February and August 2015.

Regarding total biomass, the highest catches were observed in the months of July/2011, followed by August and November/2014 (Fig. 2). The species that contributed most to this increase were Amphiarius rugispinis, Bagre bagre, Centropomus undecimalis, Cynoscion acoupa, Macrodon ancylodon, Micropogonias furnieri and Sciades proops. The results of the statistical tests also indicated seasonal similarity in the distribution of abundance $(\mathrm{F}=0.46 ; \mathrm{p}>$ $0.05)$ and biomass $(\mathrm{KW}=0.83 ; \mathrm{p}>0,05)$, from May/2011 to November/2015. The Shannon diversity index was high in May/2011, January/2012 and August/2015 (Fig. 3). The evenness was always high, with the highest averages for the months of April/2013 and August/2015 (Fig. 4). The 
ANOVA did not indicate difference between the months for the diversity indexes of Shannon $(F=0,7454 ; p>0,05)$ and evenness $(\mathrm{F}=0.92 ; \mathrm{p}>0.05)$.

The Kruskal-Wallis test indicated a significant difference in the species abundance between the sites (KW $=25.81 ; \mathrm{p}<0.05$ ), but only the Site 1 showed difference in relation to the others, confirming the preference of individuals for this area. Regarding the variation of the indexes between sites, the higher diversity of Shannon was observed for S1 (Fig. 5). For the evenness, it was verified that Site 4 showed better uniformity for the dominance of the species. The analysis of the indexes showed heterogeneity between the sites (Fig. 6).

Non-metric multidimensional scaling (NMDS) for the sampled months revealed the formation of two seasonal groups. The group A, with similarity of $61.6 \%$, formed mostly by months of dry season, and the group B with similarity of $60.4 \%$, formed mainly by months of rainy season (Fig. 7). The similarity between species indicated the formation of three groups $(1,2,3)$ (Fig. 8). Group 1 was formed by the vast majority of the fish with great influence on the abundance, biomass and frequency of observations. Group 2 was formed by the species $C$. jamaicensis, L. piquitinga, S. stellifer, $D$. rhombeus, A. tibicen, C. leiarchus, T. falcatus and $R$. horkelli. In group $3 A$. quadriscutis, $R$. lalandii and $A$. monoceros and $N$. microps.

Considering the sampling sites, the classification analysis showed the formation of three groups (I, II, III) (Fig. 9): Group I formed by the samplings carried out at site S1, located in shallower areas near the mangrove, Group II was

Tab. I. Absolute and relative frequencies (\%) of the number (N) and weight (W) of fish species collected São Marcos Bay, state of Maranhão, Brazil in the period of May/2011 to November/2015.

\begin{tabular}{|c|c|c|c|c|c|}
\hline Species & Commom name & $\mathrm{N}$ & $\%(\mathrm{~N})$ & $\mathrm{W}(\mathrm{g})$ & $\%(\mathrm{~W})$ \\
\hline Achirus lineatus (Linnaeus, 1758) & Lined sole & 140 & $3 \%$ & $7.694,62$ & $1 \%$ \\
\hline Aluterus monoceros (Linnaeus, 1758) & Unicorn leatherjacket & 1 & $0 \%$ & 140,00 & $0 \%$ \\
\hline Amphiarius rugispinis (Velenciennes, 1840) & Jurupiranga & 71 & $2 \%$ & $13.939,29$ & $3 \%$ \\
\hline Anchoa spinifer (Valenciennes, 1840) & Spicule Anchovy & 6 & $0 \%$ & 192,50 & $0 \%$ \\
\hline Aspistor quadriscutis (Valenciennes, 1840) & Bressou sea catfish & 2 & $0 \%$ & 421,04 & $0 \%$ \\
\hline Aspredinichthys tibicen (Valenciennes, 1839) & Tenbarbed banjo & 2 & $0 \%$ & 40,90 & $0 \%$ \\
\hline Bagre bagre (Linnaeus, 1766) & Coco sea catfish & 317 & $7 \%$ & $51.929,79$ & $10 \%$ \\
\hline Bairdiella ronchus (Cuvier, 1830) & Ground croaker & 365 & $9 \%$ & $4.847,86$ & $1 \%$ \\
\hline Batrachoides surinamensis (Bloch \& Schneider, 1801) & Pacuma toadfish & 15 & $0 \%$ & $5.376,78$ & $1 \%$ \\
\hline Caranx latus (Agassiz, 1831) & Horse-eye Jack & 1 & $0 \%$ & 2,10 & $0 \%$ \\
\hline Cathorops spixii (Agassiz, 1829) & Madamango sea catfish & 41 & $1 \%$ & $1.690,69$ & $0 \%$ \\
\hline Centropomus parallelus (Poey 1960) & Fat snook & 4 & $0 \%$ & $1.690,83$ & $0 \%$ \\
\hline Centropomus undecimalis (Bloch,1792) & Common snook & 109 & $3 \%$ & $50.276,72$ & $9 \%$ \\
\hline Cetengraulis edentulus (Cuvier, 1829) & Atlantic anchoveta & 42 & $1 \%$ & $1.102,74$ & $0 \%$ \\
\hline Chaetodipterus faber (Broussonet, 1782) & Atlantic spadefish & 13 & $0 \%$ & 150,88 & $0 \%$ \\
\hline Colomesus psittacus (Bloch \& Schneider, 1801) & Banded puffer & 8 & $0 \%$ & $1.768,26$ & $0 \%$ \\
\hline Cynoscion acoupa (Lacepède, 1801) & Acoupa weakfish & 98 & $2 \%$ & $33.738,16$ & $6 \%$ \\
\hline Cynoscion jamaicensis (Vaillant \& Bocourt, 1883) & Jamaica weakfish & 11 & $0 \%$ & $1.394,70$ & $0 \%$ \\
\hline Cynoscion leiarchus (Cuvier, 1830) & Smooth weakfish & 27 & $1 \%$ & $2.801,20$ & $1 \%$ \\
\hline Cynoscion microlepidotus (Cuvier, 1830) & Corvina & 32 & $1 \%$ & $6.227,11$ & $1 \%$ \\
\hline Dasyatis guttata (Bloch \& Schneider, 1801) & Longnose stingray & 3 & $0 \%$ & 799,29 & $0 \%$ \\
\hline Diapterus rhombeus (Cuvier, 1829) & Caitipa mojarra & 3 & $0 \%$ & 59,90 & $0 \%$ \\
\hline Elops saurus (Linnaeus, 1766) & Ladyfish & 11 & $0 \%$ & $1.248,64$ & $0 \%$ \\
\hline Genyatremus luteus (Bloch, 1790) & Torroto grunt & 417 & $10 \%$ & $38.709,00$ & $7 \%$ \\
\hline Gymnura micrura (Bloch \& Schneider, 1801) & Smooth butterfly ray & 3 & $0 \%$ & 336,51 & $0 \%$ \\
\hline Hexanematichthys bonillai (Miles, 1945) & New Granada sea catfish & 19 & $0 \%$ & $1.216,10$ & $0 \%$ \\
\hline Lile piquitinga (Schreiner \& Ribeiro, 1903) & Atlantic piquitinga & 93 & $2 \%$ & 383,04 & $0 \%$ \\
\hline Lobotes surinamensis (Bloch, 1790) & Tripletail & 1 & $0 \%$ & 824,00 & $0 \%$ \\
\hline Lutjanus jocu (Bloch \& Schneider,1801) & Dog snapper & 9 & $0 \%$ & $1.088,11$ & $0 \%$ \\
\hline Macrodon ancylodon (Bloch \& Schneider, 1801) & King weakfish & 370 & $9 \%$ & $56.974,09$ & $10 \%$ \\
\hline Menticirrhus americanus (Linnaeus, 1758) & Southern kingcroaker & 62 & $1 \%$ & $4.173,79$ & $1 \%$ \\
\hline Micropogonias furnieri (Desmarest, 1823) & Whitemouth croaker & 31 & $1 \%$ & $13.950,41$ & $3 \%$ \\
\hline Mugil curema (Valenciennes, 1836) & White mullet & 95 & $2 \%$ & $6.033,26$ & $1 \%$ \\
\hline Mugil gaimardianus (Desmarest, 1831) & Redeye mullet & 291 & $7 \%$ & $8.071,52$ & $1 \%$ \\
\hline Mugil incilis (Hancock, 1830) & Parassi mullet & 33 & $1 \%$ & $11.637,60$ & $2 \%$ \\
\hline Nebris microps (Cuvier, 1830) & Smalleye croaker & 1 & $0 \%$ & 260,00 & $0 \%$ \\
\hline Ogcocephalus vespertilio (Linnaeus, 1758) & Seadevil & 2 & $0 \%$ & 52,65 & $0 \%$ \\
\hline Oligoplites palometa (Cuvier, 1832) & Maracaibo leatherjacket & 8 & $0 \%$ & $1.582,26$ & $0 \%$ \\
\hline Pellona castelnaeana (Valenciennes, 1847) & Amazon pellona & 26 & $1 \%$ & $14.044,53$ & $3 \%$ \\
\hline
\end{tabular}




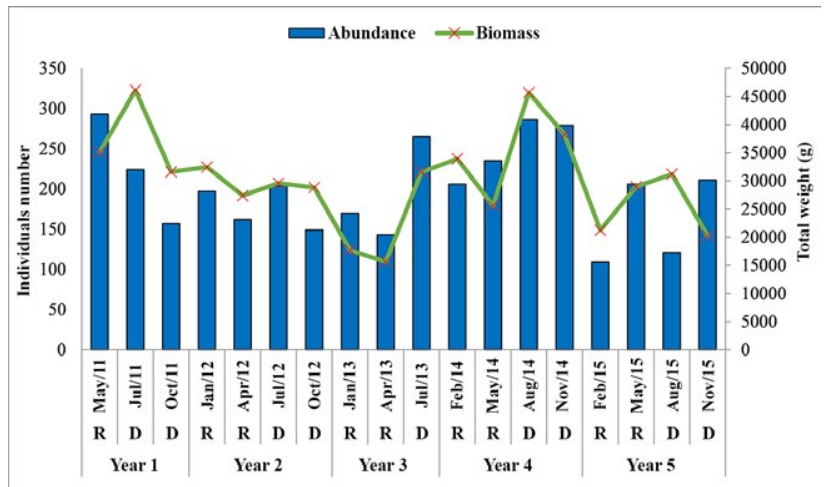

Fig. 2. Temporal variation of the number of individuals collected and biomass at São Marcos Bay, state of Maranhão, Brazil (D, drought; R, rainy).

formed by the sites S2 and S3, located in an intermediate profile regarding the hydrodynamic gradient and depth, and Group III that was represented by the site S4, which is characterized by the greater depth, greater speed of the currents and it is also located in the route of the ships that access the port terminals in the Maranhense Gulf.

SIMPER analysis performed on ichthyofaunal data detected which the species that contributed the most to the formation of group A were M. ancylodon, B. bagre and $G$. luteus, whereas $S$. proops, B. ronchus, G. luteus were the species that most contributed to the formation of group B. The dissimilarity between the seasonal groups was $39.17 \%$, and the species with the highest contribution percentage were $S$. janeiro, with a higher incidence in the dry season and M. gaimardianus, more abundant in the rainy season. Regarding the sampling sites, $B$. ronchus contributed the most to the differentiation of S1 when compared to S2, S3 and S4. It is important to highlight that $82.6 \%$ of individuals of this species were captured in S1. The dissimilarity of $\mathrm{S} 4$ in relation to $\mathrm{S} 2$ and $\mathrm{S} 3$ was associated to the higher contributions of $B$. bagre (more abundant in $\mathrm{S} 2$ ) and $M$. ancylodon (more abundant in S3).

The evaluation of the results, considering the regional seasonality (rainy and dry season), showed significant differences for the composition of the taxa, being influenced mainly by the greater abundance of the Scianidae in the dry season (ANOSIM, $\mathrm{R}=0.183, \mathrm{p}=0.02$ ). Considering the sampling points ANOSIM also indicated significant differences, with the site S1 presenting a differentiated composition in relation to the others, as well as $\mathrm{S} 4$ in relation to $\mathrm{S} 2(\mathrm{R}=0.272, \mathrm{p}=0.0001)$.

\section{DISCUSSION}

The research carried out between March/2011 and November/2015 indicates that the richness of the fish species of São Marcos Bay is inferior to those found in other tropical estuaries (AraúJo et al., 2008; PAIVA et al., 2008; CAMPos et al., 2010; SANTOS et al., 2015; CATTANi et al., 2016). In addition, studies carried out by CASTRo $(1997,2001)$ in adjacent regions (Cururuca, Paciência, Estreito, Baías,

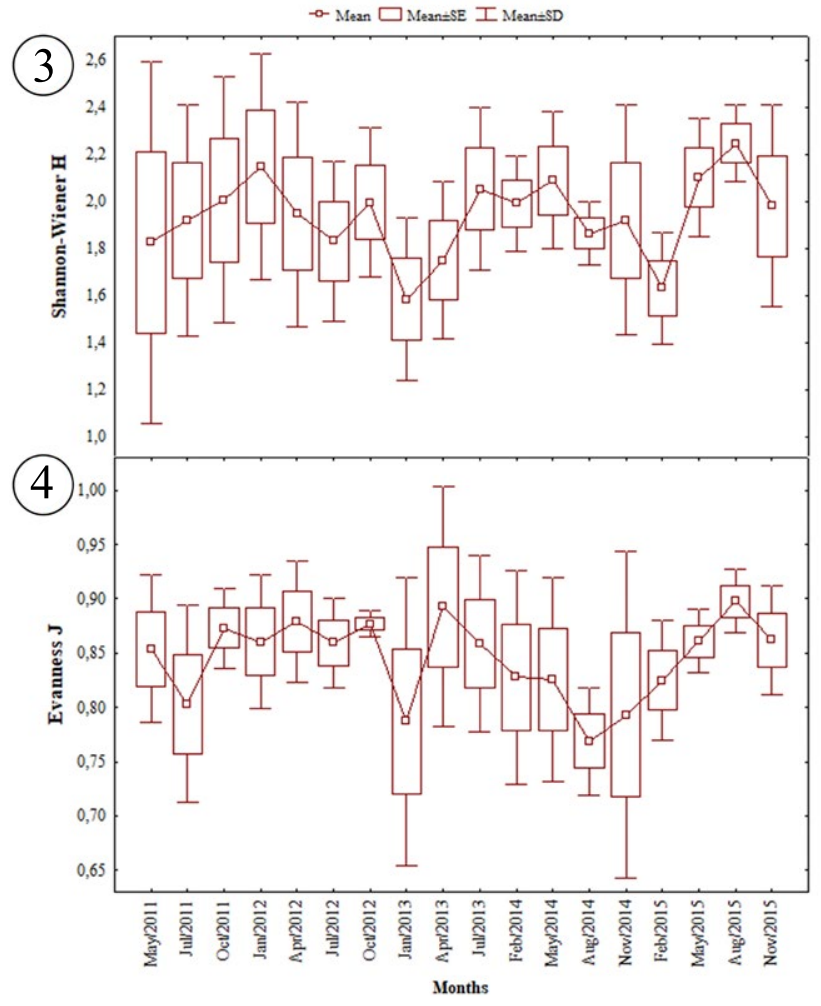

Figs. 3-4. Seasonal variation of the ecological indexes frow species of fish collected in São Marcos Bay, State of Maranhão: 3, Shannon-Wiener; 4, Evenness.

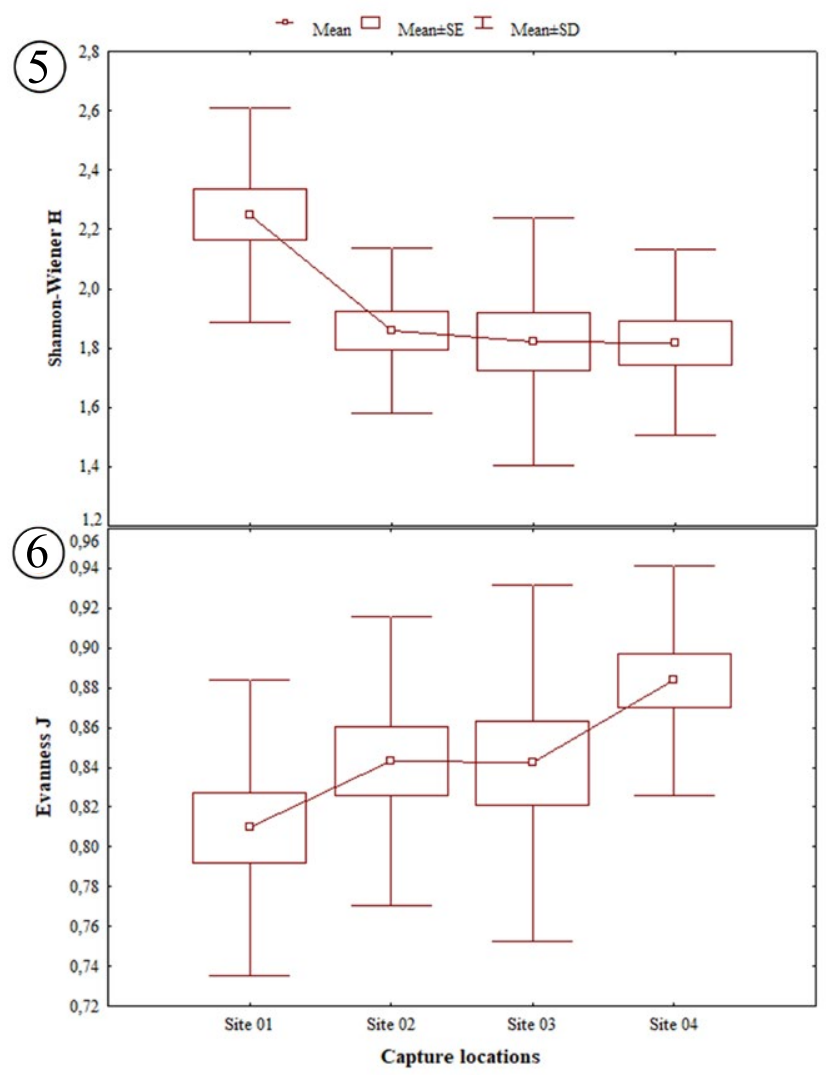

Figs. 5-6. Spatial variation of the ecological indexes frow species of fish collected in São Marcos Bay, State of Maranhão: 5, Shannon-Wiener; 6, Evenness. 


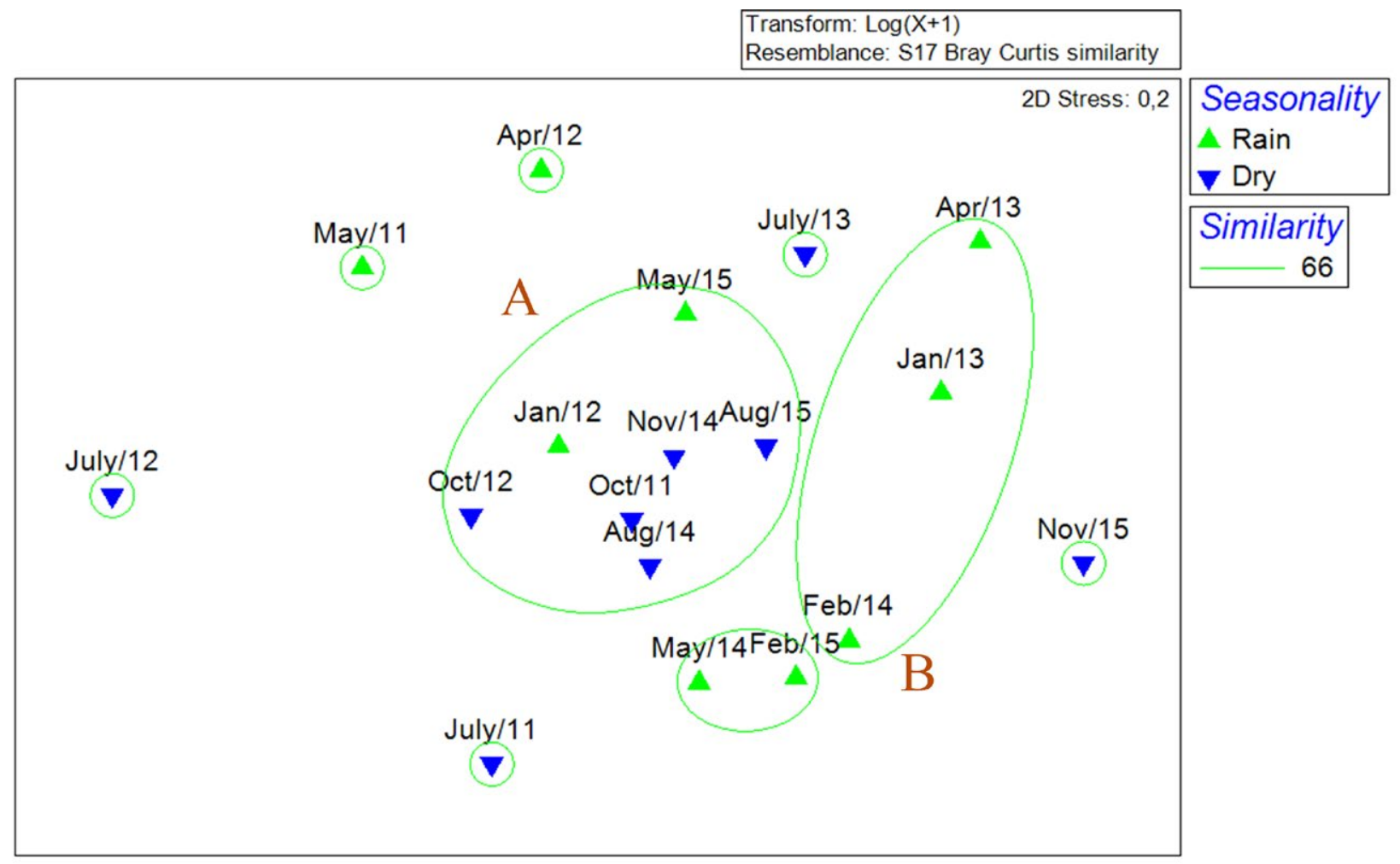

Fig. 7. Non-metric Multidimensional Scaling (NMDS) for abundance among fish assemblages for the months of capture in São Marcos Bay, Maranhão, Brazil.

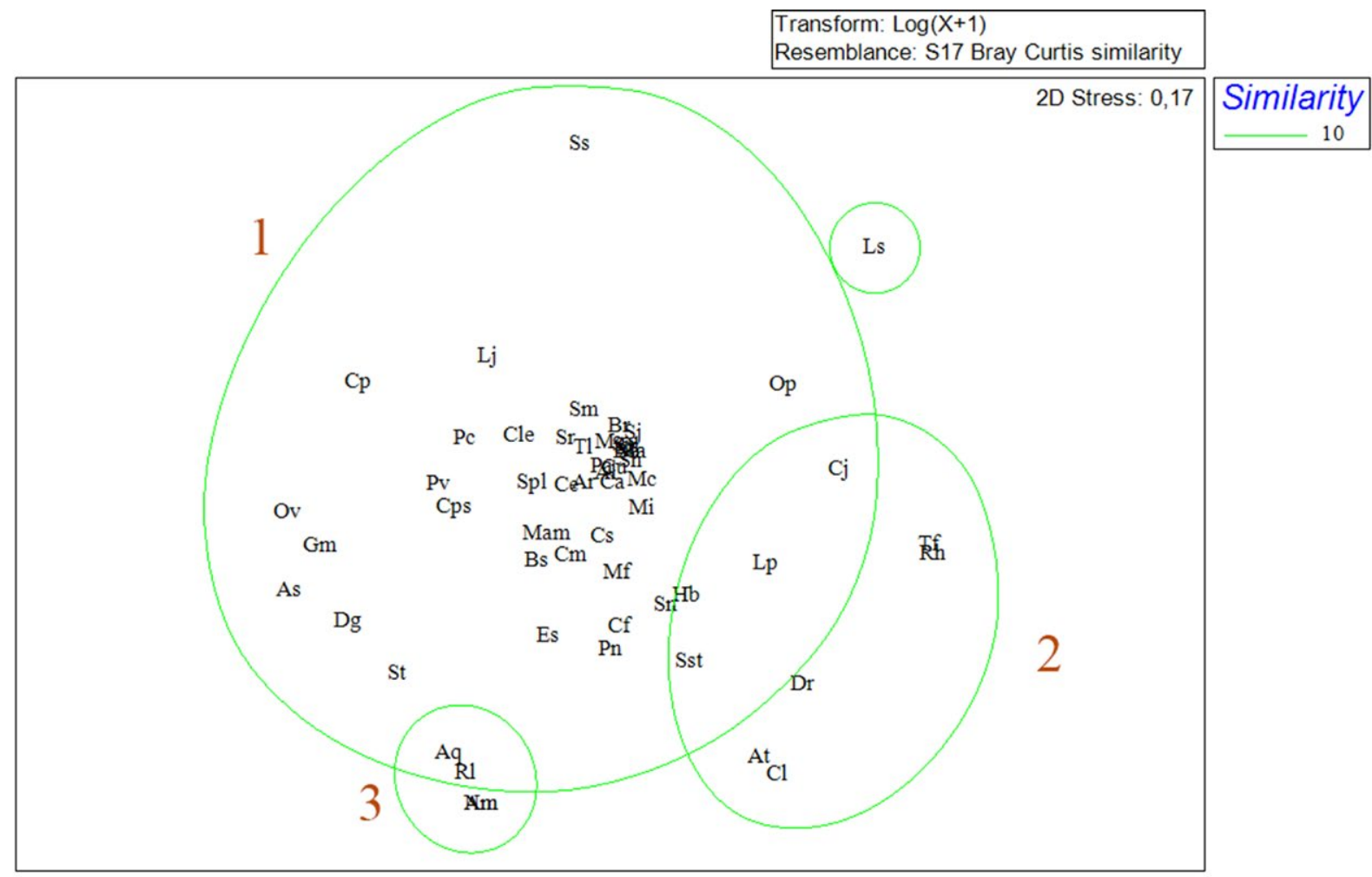

Fig. 8. Non-metric Multidimensional Scaling (NMDS) for abundance among especies capture in São Marcos Bay, Maranhão, Brazil (Al: $A$. lineatus; Am: A. monoceros; Ar: A. rugispinis; As: A. spinifer; Aq: A. quadriscutis; At: A. tibicen; Bb: B. bagre; Br: B. ronchus; Bs: B. surinamensis; Cl: C. latus; Cs: C. spixii; Cp: C. parallelus; Cu: C. undecimalis; Ce: C. edentulus; Cf: C. faber; Cps: C. psittacus; Ca: C. acoupa; $\mathrm{Cj}$ : Ci jamaicensis; Cle: $C i$ leiarchus; Cm: C. microlepidotus; Dg: D. guttata; Dr: D. rhombeus; Es: E. saurus; Gl: G. luteus; Gm: G. micrura; Hb: H. bonillai; Lp: L. piquitinga; Ls: L. surinamensis; Lj: L. jocu; Ma: M. ancylodon; Mam: M. americanos; Mf: M. furnieri; Mc: M. curema; Mg: M. gaimardianus; Mi: M. incilis; Nm: N. micros; Ov: O. vespertilio; Op: O. palometa; Pc: P. castelnaeana; Pv: P. virginicus; Pn: P. nodosus; Pa: P. atherinoides; Rh: R. horkelli; Rl: R. lalandii; Sj: S. janeiro; Sh: S. herzbergii; Sp: S. proops; Ss: S. setapinnis; Sn: S. naso; Sr: S. rastrifer; Sst: S. stellifer; Sm: S. marina; St: S. timucu; Spl: S. plagusia; Tf: T. falcatus; Tl: T. lepturus). 


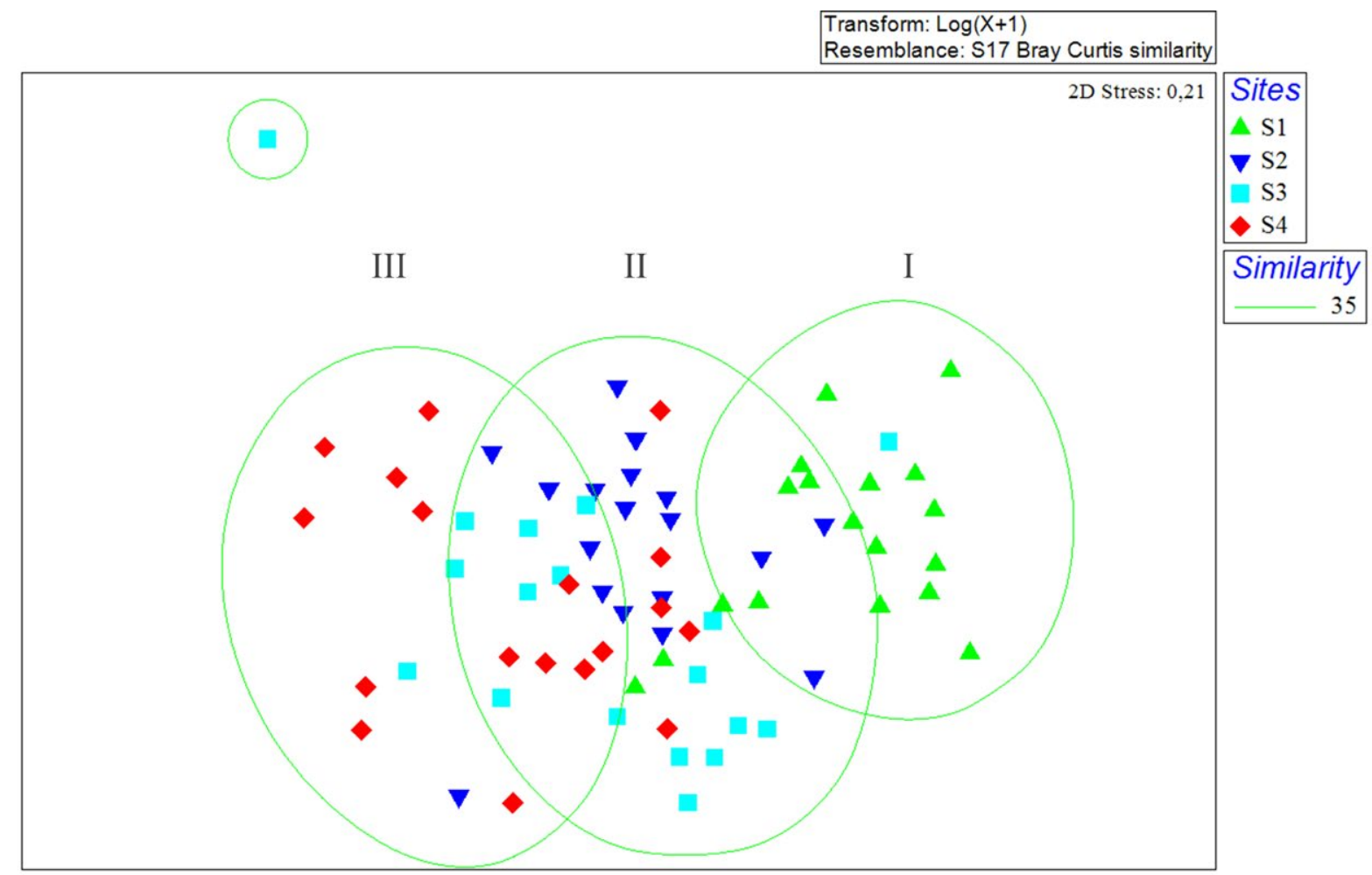

Fig. 9. Non-metric Multidimensional Scaling (NMDS) representing the results for fish abundance by sites of São Marcos Bay, Maranhão, Brazil.

Tibiri and Paciência River) also corroborate with the most significant results in terms of the number of species recorded. However, studies evaluating the ichthyofauna in sites that are part of the same estuarine system presented species richness below the values obtained in this study. PINHEIRO-JÚNIOR et al. (2005) recorded in the Anil River 43 species, while Carvalho-Neta \& CAStro (2008) in a study carried out in the Caranguejo Island, obtained a list of 32 species.

The variation of species richness among the estuaries may be associated to factors such as latitude, seasonal variability, degree of contamination by chemical pollutants and impacts that result from the joint action of several factors such as urbanization, landfills, industrial poles implantation, construction and maintenance of ports (FRANCA et al., 2011; Pasquaud et al., 2015; GuRdeK \& Acuña-Plavan, 2017; CASTRo, et al., 2017). In the specific case of São Marcos Bay, which has the second largest port structure in Brazil, several studies have identified contamination in water and sediments as a result of anthropic activities, including bioaccumulation of contaminants in fish, which may affect marine ecosystems and aquatic organisms (CARVALHO-NETA et al., 2012; SousA et al., 2013; CASTRO et al., 2018).

The predominance of species belonging to the Perciformes and Siluriformes orders with the expected pattern along the northern Brazilian coast is due to their tolerance to salinity variations, such as the species of the families Sciaenidae and Ariidae that explore estuarine habitats (CAMARGO \& ISAAC, 2003). However, significant results of species belonging to the order of the Clupeiformes were verified. The fish assembly of São Marcos Bay is strongly inhabited by small individuals mainly of the Engraulidea family, which is characterized by the formation of shoals. In the coastal region of Rio Grande do Norte, Brazil, the order Clupeiformes showed relative abundance among the species that occur in the region of Ponta Negra (GURGEL et al., 2012), even as Jaguaribe beach, Itamaracá, Pernambuco (Lira \& TeIXEIRA, 2008).

The dominance of the Sciaenidae and Ariidae families is consistent with the results found in other estuaries in the North and Northeast regions of Brazil (LIRA \& TeIXEIRA, 2008; SANDERs \& HJort, 2011; ChaO et al., 2015; Dantas et al., 2016). Both families are composed of generalist species that normally inhabit sandy-muddy soft bottoms (Menezes \& Figueiredo, 1980; Le Bail et al., 2000). Thus, the cyanide and aryid predominance may be associated with the favorable conditions found in the substrates of the estuarine environments of the region, mainly formed by sand and mud (Morais, 1977; SouZA-FILHO, 2005).

Fish assemblage of the study area was dominated by a few fish species, mainly by the sciaenid G. luteus. The taxon $G$. luteus is a widely distributed species along the western regions below the Antilles and the north coast of South America, from the eastern portion of Colombia to Brazil, classified as estuarine-marine inhabits coastal waters, especially estuaries and lagoons, with mud, sand and gravel (Cervigón, 1966; Fischer, 1978; Giarrizzo \& Krumme, 2007). It should be noted that $G$. luteus was captured during all study period, indicating high capacity of tolerance to the seasonal variations of salinity in São Marcos Bay. According to AzEvEDo et al. (2008), the Maranhense Gulf may present 
salinity of 21.8 in the rainy season, when the precipitation and discharge levels of the rivers are higher, and salinity up to 36 in the dry period, when the sun light and evaporation are more intense.

Sciades proops stands out for its high contribution to biomass and occurrence throughout the year, indicating the strong adaptive capacity that this species has developed due to oceanographic conditions in these outermost areas of São Marcos Bay. Studies about first gonadal maturation developed in this same region for $S$. proops show an atypical variation in the size of individuals as they begin their involvement in the reproductive cycle (AzEvEDo et al., 2010). The authors attributed such variations to the adaptation processes resulting from physicochemical and climatic variables that are changing in the region, as well as a response to the fishing effort directed to this species.

Studies in Brazilian estuaries show that estuarine fish assemblages undergo clear seasonal fluctuations in biomass and diversity, which may be related to reproductive patterns, increased recruitment, and, even indirectly, to rainfall (BARLETTA-BERGAN et al., 2002; BARLETTA et al., 2003, 2007; VILAR et al., 2011). Such temporal changes in abundance in the community in this area, although not addressed in any integrated analysis among the fish, did not present significant differences.

Collectively, fish assemblages during both seasons were comprised of many rare species and a few species in large numbers, a frequent characteristic for estuarine fish populations (WHITFIELD 1989, 1999; TZENG \& WANG, 1992; Neira \& Potter, 1994; Barletta-Bergan et al., 2002; BARLETTA et al., 2003). However, fish fauna peaked in abundance in the dry season. This pattern was mainly driven by $G$. luteus, L. piquitinga, B. ronchus, S. proops, $S$. janeiro, $M$. ancylodon and $M$. gaimardianus. The species that contributed the most to the total biomass are highly predominant in the coast of Maranhão (AzEVEDo et al., 2008; Carvalho-Neta \& Castro, 2008; Carvalho-Neta et al., 2012; AzEVEDo et al., 2012; Almeida et al., 2016; AzEvedo et al., 2017). Cyclic changes in the intertidal fish fauna did not affect overall density and biomass throughout the years. Similar numbers and standing stock was apparently maintained year-round. This suggests that the increases in abundance or weight in some species were compensated by reductions in others (GIARRIZZO \& KRUMME, 2007).

The sites 2, 3 and 4 analyzed in the present study are located furthest from the areas of mangrove vegetation, while the site 1 is located in a more sheltered area, with a lower interference from the port area. Mangrove areas act as shelter, breeding ground and food source for various organisms, while several fish species use this habitat for their biological and ecological activities (MOREIRA OsóRIO et al., 2011). GIARRIZzo \& KRUMME (2007) propose that landscape factors may be important in structuring mangrove fish assemblages, for example, the position relative to the ocean or to the mainland, irrespective of salinity, as well as the proximity to an extensive subtidal resting area where the intertidal fishes may spend the low tide period. The natural characteristics of each environment and the environmental factors may explain the observed differences between the sampling points.

Analysis of similarity showed a differentiated seasonal occurrence for composition of fish assemblage in São Marcos Bay. Similar results were verified by MourÃo et al. (2015) in Amazon Estuary of Pará, and VeIGA et al. (2006) in southern Portugal, at where such seasonal variations in composition of fish were justified as a common feature of dynamic ecosystems, such as estuaries. GURDEK \& ACUÑAPLAVAN (2017) observed regular seasonal changes in the fish community structure in the lower portion of an estuary in the Estuary of Pando, Uruguay, which reinforces the idea of considering both environmental variability and life cycles of fish species when addressing temporal variability in estuarine environments. Some taxa form shoals and seek estuarine areas to carry out their breeding activities. Seasonal peaks are generally attributed to the arrival of juveniles of many marine species that use shallow water ecosystems as nurseries (DulCiC et al., 1997; CABRAL, 1999).

The NMDS showed differentiation of the species with occurrence both in the rainy season and in the dry season. This situation can be attributed mainly to the registration of occasional species in the area, since many juvenile species were present in the samplings, suggesting that the area acts as a nursery and as a place of growth of many organisms. In the estuary of Michoacan, SANDOvAL-HuERTA et al. (2014) verified the occurrence of several juvenile individuals, evidencing the fish preference for these areas, in the initial stage of life.

The similarity of group 1, observed for the 56 taxa identified in São Marcos Bay - Amazônia Oriental, connected two major subgroups, the first one formed by species present in all campaigns, with high values of abundance and biomass, in addition to high relevance for artisanal fishing in the region. CARVAlHO-NeTA \& CASTRO (2008) states that the presence of these individuals, in the São Marcos Bay, indicates that this estuarine presents an important ecological role for breeding fish that have an economic importance for artisanal fishing in the state of Maranhão. Group 2 showed species present only at certain periods of the year, showing defined intolerance to variations in the environment, considering that the temporal distribution of adults and juveniles is strongly influenced by changes in environmental factors such as temperature and salinity (YÁÑEZ-ARANCIBIA, 1985; LAROCHE et al., 1997).

The group 3 included species where the grouping pattern presented seems to be associated to the low levels of occurrence of the individuals, which suggests that these species are rare in the area where the study was carried out. The richness and composition of rare species may be related to the characteristics of the estuary, such as the degree of connectivity with the ocean and the volume of the water body (Mendoza et al., 2009).

The low diversity observed during the study may be a reflection of the port activities that historically take place in the study area. However, it was still observed that 
regional diversity was maintained throughout the study period. However, the spatial distribution of the species showed variation regarding the sampling sites, with richness presenting patterns of differentiation similar to diversity. These data indicate the need for water and sediment quality monitoring, as well as the use of bioindicators capable of predicting relation between habitat integrity and fish species, as commonly provided by environmental monitoring programs (OLIVEIRA et al., 2008).

The wide use of the São Marcos Bay area by different ichthyofaunistic groups reveals its importance for the development of the ichthyofauna of the Maranhense Gulf, with the continuous presence of several representatives of the families Scianidae, Mugilidae, Clupeidae and Engraulidae. The present results provide a better understanding of the importance of ecological information about ichthyofauna in tropical estuaries in order to include appropriate descriptors in conservation or restoration processes of marine communities and habitats.

Acknowledgments. We would like to thank the Department of Oceanography and Limnology, linked to the Universidade Federal do Maranhão, for funding the research, the Master Program in Aquatic Resources and Fisheries (PPGRAP/UEMA) of the Universidade Estadual do Maranhão, for the development of data analysis, the Coordination for the Improvement of Higher Education Personnel (CAPES) and Maranhão Foundation for the Protection of Research and Scientific and Technological Development (FAPEMA).

\section{REFERENCES}

Almeida, Z. F.; Santos, N. B.; Sousa, H. L.; Carvalho-Neta, R. N. F. \& ANDRADE, T. S. O. M. 2016. Biologia reprodutiva da pescada amarela (Cynoscion acoupa) capturada na baía de São Marcos, Maranhão, Brasil. Biota Amazônica 6(1):46-54.

Araujo, C. C. V.; Rosa, D. M.; Fernandes, J. M., Ripoli L. V. \& Krohling, W. 2008. Composição e estrutura da comunidade de peixes de uma praia arenosa da Ilha do Frade, Vitória, Espírito Santo. Iheringia, Série Zoologia 98(1):129-135.

Araújo, F. G.; Azevedo, M. C. C.; Silva, M. A.; Pessanha, A. L. M.; Gomes, I. D. \& Cruz-Filho, A. G. 2002. Environmental influences on the demersal fish assemblages in the Sepetiba Bay, Brazil. Estuaries 25:441-450.

Araújo, F. G.; Cruz-Filho, A. G.; Azevedo, M. C. C. \& Santos, A. C. A. 1998. Estrutura da comunidade de peixes demersais da Baía de Sepetiba, RJ. Revista Brasileira de Biologia 58(3):417-430.

Araúso, F. G.; Cruz-Filho, A. G.; Azevedo, M. C. C.; Santos, A. C. A. \& Fernandes, L. A. M. 1997. Estrutura da comunidade de peixes jovens da margem continental da Baía de Sepetiba, RJ. Acta Biológica Leopoldensia 19:61-83.

Assis, K. M. M.; Santos, R. O. C. S.; Cutrim, S. S. \& Samyr, J. C. 2013. Planejamento Estratégico no Setor Portuário: estudo de caso de portos do Nordeste. São Luís, Estado do Maranhão. 32p.

Azevedo, A. C. G.; Feitosa, F. A. N. \& Koening, M. L. 2008. Distribuição espacial e temporal da biomassa fitoplanctônica e variáveis ambientais no Golfão Maranhense, Brasil. Acta Botanica Brasilica 22(3):870-877.

Azevedo, J. W. J.; Castro, A. C. L.; Porto, H. L. R. \& Lima, P. R. S. 2010. Comprimento e idade na primeira maturidade sexual do uritinga, Sciades proops (Valenciennes, 1840)(Siluriformes: Ariidae), capturado no litoral ocidental do Maranhão, Brasil. Arquivos de Ciências do Mar 43(2):96-102.

Azevedo, J. W. J.; Castro, A. C. L.; Soares, L. S.; Silva, M. H. L.; Ferreira, H. R. S. \& Magalhães, L. A. 2012. Comprimento médio de primeira maturação para a tilápia do nilo, Oreochromis niloticus, LINNAEUS, 1758 (Perciformes: Cichlidae) capturado na bacia do Bacanga, São Luís, MA. Boletim do Laboratório de Hidrobiologia 25(1):49-54.
Azevedo, J. W. J.; Castro, A. C. L. \& Silva, M. H. L. 2017. Length-weight relation, condition factor and gonadosomatic index of the whitemouth croaker, Micropogonias furnieri (Desmarest, 1823) (Actinopterygii: Sciaenidae), caught in Lençóis Bay, state of Maranhão, eastern Amazon, Brazil. Brazilian Journal of Oceanography 65(1):1-8.

Barletta, M. \& CostA, M. F. 2009. Living and Non-living Resources Exploitation in a Tropical Semi-arid Estuary. Journal of Coastal Research 56:371-375.

Barletta, M.; Amaral, C. S.; Correa, M. F. M.; Guebert, F.; Dantas, D. V.; LorenzI, L. \& SAINT-PAul, U. 2008. Factors affecting seasonal variations in demersal fish assemblages at an ecocline in a tropicalsubtropical estuary. Journal of Fish Biology 73:1314-1336.

Barletta, M.; Barletta-Bergan, A.; Saint-Paul, U. \& Hubold, G. 2003. Seasonal changes in density, biomass, and diversity of estuarine fishes in tidal mangrove creeks of the lower Caeté Estuary (northern Brazilian coast, east Amazon). Marine Ecology Progress Series 256:217-228.

Barletta-Bergan, A.; Barletta, M. \& Saint-Paul, U. 2002. Structure and seasonal dynamics of larval fish in the Caeté river estuary in north Brazil. Estuarine, Coastal and Shelf Science 54:193-206.

Borges, P. A.; Train, S.; Dias, J. D. \& Bonecker, C. C. 2010. Effects of fish farming on plankton structure in a Brazilian tropical reservoir. Hydrobiologia 649:279-291.

CABral, H. N. 1999. Ictiofauna do Estuário do Sado. Relatórios Científicos e Técnicos do Instituto de Investigação das Pescas e do Mar 47:30.

CAmargo, M. \& IsAaC, V. 2003. Ictiofauna estuarina. In: FernANDES, M. E. B., ed. Os manguezais da costa norte brasileira. Maranhão, Fundação Rio Bacanga, p. 105-132.

Campos, C. E. C.; SÁ-Oliveira, J. C. \& Araújo, A. S. 2010. Composição e estrutura de comunidades de peixes nos Parrachos de Muriú, Estado do Rio Grande do Norte, Brasil. Arquivos de Ciências do Mar 43(1):63-75.

Carvalho-Neta, R. N. F. \& Castro, A. C. L. 2008. Diversidade das assembleias de peixes estuarinos da Ilha dos Caranguejos, Maranhão. Arquivos de Ciências do Mar 41(1):48-57.

Carvalho-Neta, R. N. F.; Sousa, D. B. P.; Almeida Z. S.; Santos D. M. S. \& TCHAICKA, L. 2014. A histopathological and biometric comparison between catfish (Pisces, Ariidae) from a harbor and a protected area, Brazil. Aquatic Biosystems 10(12):1-7

Carvalho-Neta, R. N. F.; Torres Jr, A. R. \& Abreu-Silva, A. L. 2012. Biomarkers in Catfish Sciades herzbergii (Teleostei: Ariidae) from Polluted and Non-polluted Areas (São Marcos' Bay, Northeastern Brazil). Applied Biochemistry and Biotechnology 166(5):1314-1327.

CAstro, A. C. L. 2001. Diversidade da assembléia de peixes em igarapés do estuário do Rio Paciência (MA-Brasil). Atlântica 23:61-72.

Castro, A.C.L. 1997. Características ecológicas da icfiofauna da Ilha de São Luís-MA. Boletim do Laboratório de Hidrobiologia 10:1-18.

Castro, J. S.; França, C. L.; Fernandes, J. F. F.; Silva J. S.; CarvalhoNetA, R. N. F.\& Teixeira, E. G. 2018. Biomarcadores histológicos em brânquias de Sciades herzbergii (Siluriformes, Ariidae) capturados no Complexo Estuarino de São Marcos, Maranhão. Arquivo Brasileiro de Medicina Veterinária e Zootecnia 70(2):410-418.

Castro, T. C. S.; Castro, A. C. L.; Soares, L. S.; Silva, M. H. L.; Silva F., H. R.; Azevedo, J. W. J. \& Franca, V. L. F. 2017. Social and Environmental Impacts on Rural Communities Residing Near the Industrial Complex of Sao Luis Island, State of Maranhão, Brazil. Journal of Sustainable Development 10:249-260.

Cattani, A. P.; Jorge, F. G. D.; Ribeiro, G. C.; Wedekin, L. L.; Lopes, P. C. A. S.; RupIL, G. M. \& SPACH, H. L. 2016. Fish assemblages in a coastal bay adjacent to a network of marine protected areas in southern Brazil. Brazilian Journal of Oceanography 64(3):295-308.

Cervigón, F. 1966. Los peces marinos de Venezuela. Caracas, Fundación La Salle de Ciências Naturales. 436p.

Cervigón, F.; Cipriani, R.; Fischer, W.; Garibaldi, L.; Hendrickx, M.; Lemus, A. J.; Márquez, R.; Poutiers, J. M.; Robaina, G. \& Rodriguez, B. 1992. Fichas FAO de identificación de especies para los fines de la pesca: guía de campo de las especies comerciales marinas y de aquas salobres de la costa septentrional de Sur América. Rome, FAO. 513p.

Chao, N. L.; Lucena Frédou, F.; Haimovici, M.; Peres, M. B.; Polidoro, B.; Raseira, M.; Subirá, R. \& Carpenter, K. 2015. A popular and potentially sustainable fishery resource under pressure-extinction risk and conservation of Brazilian Sciaenidae (Teleostei: Perciformes). Global Ecology and Conservation 4:117-126. 
Clarke, K. R. 1993. Non-parametric multivariate analyses of changes in community structure. Australian Journal of Ecology 18:117-143.

Clarke, K. R., \& Gorley, R. N. 2006. PRIMER v6: User Manual/ Tutorial. Plymouth, Plymouth Marine Laboratory.

Clarke, K. R. \& Warwick, R. M. 1994. Change in Marine Communities. An Approach to Statistical Analysis and Interpretation. Plymouth, Natural Environment Research Council. 144p.

Dantas, N. C. F. M.; Silva Júnior, C. A. B.; Feitosa, C. V. \& Carneiro, P. B. M. 2016. Seasonal influence of drifting seaweeds on the structure of fish assemblages on the eastern equatorial Brazilian coast. Brazilian Journal of Oceanography 64(4):365-374.

Dulcic, J.; Kraluevic, M.; Grbec, B. \& Pallaoro, A. 1997. Composition and temporal fluctuations of inshore juvenile fish populations in the Kornati Archipelago, eastern middle Adriatic. Marine Biology 129:267277.

Falcão, M. G.; Pichler, H. A.; Félix, F. C.; Spach, H. L; Barril, M. E.; Araujo, K. C. B. \& Godefroid, R. S. 2008. A ictiofauna como indicador de qualidade ambiental em planícies de maré do Complexo Estuarino de Paranaguá, Brasil, Cadernos da Escola de Saúde Ciências Biológicas 1:1-16.

Figueiredo, J. L. \& Menezes, N. A. 1980. Manual de peixes marinhos do sudeste do Brasil. III. Teleostei (2). São Paulo, Museu de Zoologia da Universidade de São Paulo. 90p.

Figueiredo, J.L. \& Menezes, N.A. 2000. Manual de peixes marinhos do sudeste do Brasil. VI. Teleostei (5). São Paulo, Museu de Zoologia da Universidade de São Paulo. 116p.

Fisch, F.; BRANCO, J. O. \& MENEZES, J. T. 2016. Ictiofauna como indicador de la integridad biótica de um ambiente estuarino. Acta Biológica Colombiana 21(1):27-38.

FISCHER, W. 1978. FAO species identification sheets for fishery purposes. Western Central Atlantic (fishing area 31). Vols. 1-7. Roma, FAO.

Franca, S.; Costa, M. J. \& CABral, H. N. 2011. Padrões de variabilidade da assembléia de peixes inter e intra-estuarinos ao longo da costa portuguesa. Estuarine, Coastal and Shelf Science 91:262-271.

Froese, R. \& Pauly, D. 2009. FishBase. World Wide Web electronic publication. Available on <http://www.fishbase.org/home.htm $>$. Accessed at February

Giarrizzo, T. \& Krumme, U. 2007. Spatial differences and seasonal cyclicity in the intertidal fish fauna from four mangrove creeks in a salinity zone of the Curuçá Estuary, North Brazil. Bulletin of Marine Sciences 80(3):739-754.

Gurdek, R. \& Acuña-Plavan, A. 2017. Temporal dynamics of a fish community in the lower portion of a tidal creek, Pando sub-estuarine system, Uruguay. Iheringia, Série Zoologia 107:e2017003.

Gurgel, T. A. B.; Oliveira, M. R.; Brasil, D. F. \& Sellappa, S. 2012. Peixes marinhos das águas costeiras de Ponta Negra, Rio Grande do Norte, Brasil. Biota Amazônica 2(1):83-97.

Hammer, Ø.; Harper, D.A.T. \& RyAn, P. D. 2001. PAST: Paleontological Statistics Software Package for Education and Data Analysis. Palaeontologia Electronica 4(1):1-9.

KimMERER, W. J. 2002. Effects of freshwater flow on abundance of estuarine organisms: physical effects or trophic linkages? Marine Ecology Progress Series 243:39-55.

LARA, E. N. \& GonzÁlez, E. A. 1998. The relationship between reef fish community structure and environmental variables in the southern Mexican Caribbean. Journal of Fish Biology 53:209-221.

Laroche, J.; Baran, E. \& Rasoanandrasana, N. B. 1997. Tempora patterns in a fish assemblage of a semiarid mangrove zone in Madagascar. Journal of Fish Biology 51:3-20.

Le bail, P. Y.; Keith, P. \& Planquette, P. 2000. Atlas des poissons d'eau douce de Guyane. (tome 2, fascicule II). Paris, Publications scientifiques du Muséum national d'Histoire naturelle. 307p.

LirA, A. K. F. \& Teixeira, S. F. 2008. Ictiofauna da praia de Jaguaribe, Itamaracá, Pernambuco. Iheringia, Série Zoologia 98(4):475-480.

LONERAGAN, N. R. 1999. River flows and estuarine ecosystems: implications for coastal fisheries from a review and a case study of the Logan river, southeast Queensland. Australian. Journal of Ecology 24:431-440.

Maes, J.; Talllieu, A.; Dammme, P. A.; Correnie, K. \& Ollevier, F. 1998 Seasonal patterns in the fish and crustacean community of a turbid temperate estuary (Zeeschelde Estuary, Belgium). Estuarine, Coastal and Shelf Science 47:143-151.
Marshall, S. \& Elliott, M. 1998. Environmental influences on the fish assemblage of the Humber estuary, UK. Estuarine, Coastal and Shelf Science 46:175-184.

Mendoza, E.; Castillo-Rivera, M.; Zárate-Hernández, R. \& OrtizBurgos, S. 2009. Seasonal variations in the diversity, abundance, and composition of species in an estuarine fish community in the Tropical Eastern Pacific, Mexico. Ichthyological research 56:330-339.

Menezes, N. A. \& Figueiredo, J. L. 1980. Manual de Peixes marinhos do sudeste do Brasil. IV Teleostei (3). São Paulo, Museu de Zoologia da Universidade de São Paulo. 96p.

Morais, J. O. 1977. Processos de sedimentação na Baía de São Marcos, Estado do Maranhão, Brasil. Arquivos de Ciências do Mar 17(2):153164.

Moreira Osório, F.; Oliveira Godinho, W. \& Lotufo, T. M. D. C. 2011 Ictiofauna associada às raízes de mangue do estuário do Rio Pacoti-CE, Brasil. Biota Neotropical 11(1):415-420.

MourÃo, K. R. M.; Frédou, T. \& FrÉdou, F. L. 2015. Spatial and seasonal variation of the ichthyofauna and habitat use in the inner portion of the Brazilian Amazon Estuary. Boletim do Instituto de Pesca 41(3):529-545.

NeIrA, F. J. \& Potter, I. C. 1994. The larval fish assemblage of the NornalupWalpole estuary, a permanently open estuary on the southern coast of western Australia. Australian Journal of Marine Freshwater Research 45:1193-1207.

Nero, V. L. \& Sealey, K. S. 2006. Fish-environment associations in the coastal waters of Andros Island, The Bahamas. Environmental Biology of Fishes 75:223-236.

Oliveira, R. B. D. S.; Castro, C. M. \& Baptista, D. F. 2008. Desenvolvimento de índices multimétricos para utilização em programas de monitoramento biológico da integridade de ecossistemas aquáticos. Oecologia Brasiliensis 12(3):9-21.

Paiva, A. C. G.; Chaves, P. T. C. \& Araúuo, M. E. 2008, Estrutura organização trófica da ictiofauna de águas rasas em um estuário tropical. Revista Brasileira de Zoologia 25(4):647-661.

Pasquaud, S.; Vasconcelos, R. P.; Franca, S.; Henriques, S.; Costa, M. J. \& CABral, H. N. 2015. Padrões mundiais de biodiversidade de peixes em estuários: efeito de fatores globais vs. locais. Ciências Estuarinas, Costeiras e de Prateleiras 154:122-128.

Pinheiro-Júnior, J. R.; Castro, A. C. L. \& Gomes, L. N. 2005. Estrutura da comunidade de peixes do estuário do Rio Anil, Ilha de São Luís, Maranhão. Arquivos de Ciências do Mar 38:29-37.

SANDERS, J. S. \& HJORT, A. 2011. Marine protected areas country case studies on policy, governance and institutional issues. FAO Fisheries and Aquaculture Technical Paper, 556/1. FAO, Rome.

Sandoval-Huerta, E. R.; Madrigal-Guridi, X.; Escalera-VÁzQuez, L. H.; Medina-Nava, M. \& Domínguez-Domínguez, O. 2014. Estructura de la comunidad de peces en cuatro estuarios del Pacífico mexicano central. Revista Mexicana de Biodiversidad 85:1184-1196.

Santos, J. A. P.; Schmiegelow, J. M. M.; Rotundo, M. M. \& Barrella, W. 2015. Composição e variação temporal da assembleia de peixes do alto sistema estuarino de Santos, São Paulo, Brasil. Boletim do Instituto de Pesca 41(4):945-959.

Shapiro, S. S. \& WilK, M. B. 1965. An analysis of variance test for normality (Complete samples). Biometrika 52:591-611.

Silva-Júnior, M. G.; Castro, A. C. L.; Saint-Paul, U. \& Porto, H. L. R. 2013. Caracterização da ictiofauna em três canais de maré do estuário do Rio Paciência, Ilha de São Luís, Estado do Maranhão. Arquivos de Ciências do Mar 46(1):5-21.

Sokal, R. R. \& Rohlf, J. F. 1969. Biometria. New York, Freeman W.H. and Company. 832p.

Sousa, D. B. P.; Almeida, Z. S. \& Carvalho-Neta, R. N. F. 2013 Biomarcadores histológicos em duas espécies de bagres estuarinos da Costa Maranhense, Brasil. Arquivo Brasileiro de Medicina Veterinária e Zootecnia 65(2):369-376

SouzA-Filho, P. W. M. 2005. Costa de manguezais de macromaré da Amazônia: cenários morfológicos, mapeamento e quantificação de áreas usando dados de sensores remotos. Revista Brasileira de Geofísica 23(4):427-435

StrIDE, R. K. 1992. Diagnóstico da pesca artesanal marinha do Estado do Maranhão. São Luís, CORSUP/EDUFMA. 205p. 
Thiel, R.; Sepúlveda, A.; Kafemann, R. \& Nellen, W. 1995. Environmental factors as forces structuring the fish community of the Elbe estuary. Journal of Fish Biology 46:47-69.

TzEnG, W \& WANG, Y. 1992. Structure, composition and seasonal dynamics of the larval and juvenile fish community in the mangrove estuary of Tanshui River, Taiwan. Marine Biology 113:481-490.

Veiga, P.; Vieira, L.; Bexiga, C.; SÁ, R. \& Erzini, K. 2006. Structure and temporal variations of fish assemblages of the Castro Marim salt marsh, southern Portugal. Estuarine, Coastal and Shelf Science 70:27-38.

ViAnA, A. P. \& LuCENA Frédou, F. 2014. Ichthyofauna as bioindicator of environmental quality in an industrial district in the amazon estuary, Brazil. Brazilian Journal of Biology 74(2):315-324.

Vilar, C. C.; Spach, H. L. \& Joyeux, J. C. 2011. Spatial and temporal changes in the fish assemblage of a subtropical estuary in Brazil: environmental effects. Journal of the Marine Biological Association of United Kingdom 91(3):635-648.

WHITFIELD, A. K. 1989. Ichthyoplankton interchange in the mouth region of a southern African estuary. Marine Ecology Progress Series 54:25-33

Whitfield, A. K. 1999. Ichthyofaunal assemblages in estuaries: a South African case study. Reviews in Fish Biology and Fisheries 9:151-186.

Whitfield, A. K. \& Elliott, M. 2002. Fishes as indicators of environmental and ecological changes within estuaries: a review of progress and some suggestions for the future. Oxford. Journal of Fish Biology 60(A):1-22.

Yáñez-Arancibia, A.; LARA-Domínguez, A. L. \& PAuly, D. 1994. Coastal lagoons as fish habitat. In: KJERFVE, K. ed. Coastal lagoon processes. Elsevier Oceanography Series 60:363-376. 